Acta Baltico-Slavica, 45

Warszawa 2021

\begin{abstract}
Citation: Stępnik, K. (2021). The paradigm of Finnish reviews of Without Dogma by Henryk Sienkiewicz: Observations on the issue of intercultural communication and the functioning of common motifs of European culture. Acta Baltico-Slavica, 45, Article 2450. https://doi.org/10.11649/abs. 2450
\end{abstract}

\author{
Krzysztof Stępnik \\ Maria Curie-Skłodowska University \\ Lublin \\ krzysztof.stepnik@poczta.umcs.lublin.pl \\ http://orcid.org/0000-0003-4172-231X
}

\title{
The Paradigm of Finnish Reviews of Without Dogma by Henryk Sienkiewicz: Observations on the Issue of Intercultural Communication and the Functioning of Common Motifs of European Culture
}

This article is devoted to the paradigmatic description of Finnish press reviews which appeared following the release of the Finnish edition of the novel Without Dogma by the renowned Polish writer Henryk Sienkiewicz. The original work was published in instalments in the Polish press between 1889 and 1890, and the book was issued in $1890 .{ }^{1}$ The novel achieved a substantial popularity on the European book market, which may be confirmed by the fact that it was translated into several languages, including German, Russian, English, French, Danish, Swedish, Czech and Slovenian. The Finnish translation was released in autumn 1913 and its author was Maila Talvio, a writer, literary critic and an outstanding translator of Sienkiewicz's works. Unlike

${ }^{1}$ Bez dogmatu (Without Dogma) was printed in instalments in the daily papers, first in Słowo from no. 271 in 1889 to no. 229 in 1890, and then in Czas and Dziennik Poznański. The novel was published in the book form as early as in 1890 under the imprint of Stowo. Several subsequent editions were published before the Great War - in 1891, 1896, 1899, 1900, 1906 and 1912 (Świerczyńska, 2015, p. 114).

This is an Open Access article distributed under the terms of the Creative Commons Attribution 3.0 PL License (creativecommons.org/licenses/by/3.0/pl/), which permits redistribution, commercial and noncommercial, provided that the article is properly cited. (C) The Author(s) 2021. 
in the case of the translations strictly following the original title Bez dogmatu (Ohne Dogma, Bez dogmata, Without Dogma, Sans dogme, etc.), Talvio decided to change it in the Finnish edition to Anielka, which somewhat impacted the opinions of the reviewers. The change shifted the attention of the reader, at least to a certain degree, away from the main character, Leon Płoszowski, who reveals his thoughts and feelings in the form of an intimate diary, and focused it on Anielka, the object of his obsession, whose love he first despises only to later try to regain it after she marries, out of desperation, another man.

Translations do not function in an abstract domain but rather in a certain field of cultural community, even when almost everything seems to separate the readers of the original and the readers of the translation into a given language (Derrida, 2001, p. 179). The Finns and the Poles created their separate cultures on different social foundations; they were separated by space so distant that the only thing they could feel towards each other was the feeling of strangeness: racial (Ugro-Finns and Slavs), political (especially in their approaches to Russia in the nineteenth century) and religious, since the former were Lutheran and the latter - Catholic. Despite all this the two cultures seemingly so distant managed to establish some kind of mutual correspondence. And this is interesting as a hidden substrate of a broader and deeper issue for the matters we are analysing regarding the reviews in the Finnish press which discuss the content and artistic value of Without Dogma.

There were twelve reviews ${ }^{2}$ of the novel by Sienkiewicz in Finland and we will discuss them not as a set consisting of separate components (an aggregate) but rather as a paradigm, an abstracted structure derived from individual texts, formed by elements which may be compared to common denominators. The subject matter of this article will thus be a description of the review paradigm concerning Without Dogma, bearing in mind that it has been formed on the basis of only twelve texts. Such an approach has one significant advantage: we can possibly notice certain common nodal points in individual reviews and thus synthesise their contents.

2 For details see a full list at the end of this article; references to particular reviews are made using their numbers on the list. The first of them appeared in Aamulehti on 15 October 1913 (no. 238) and was republished in over twenty daily papers in October and November the same year. This short review emphasised the value of idealism in the creation of Anielka's character; the fact that it was republished in numerous journals in Finland indicates that this aspect was the key element in the marketing campaign of Otava Publishing House. The number of the reviews is strikingly high. Most of them are recorded in Finnish Literature in Poland, Polish Literature in Finland: Comparative Reception Study from a Hermeneutic Perspective, but with incorrect publication dates (Szal, 2013, unnumbered page in "VI. Attachments"). Szal writes that Without Dogma, translated into Finnish by Maila Talvio, was published as early as in 1890 . This information has not been confirmed by any data. The Swedish and Danish translations of Bez dogmatu, published in 1902, received several individual reviews. In Italy - where almost all works by Sienkiewicz had already been translated at the time - the novel received only five reviews; moreover, these texts sometimes contained glaring errors (Bernardini, 2018, p. 83). 
The method applied in this article draws on the research perspective of cultural and literary communication, including some references to poststructuralist and hermeneutical strands. The central category in this case is the press review, i.e. a text which concerns a literary work and makes a recommendation to the prospective reader. In the case of works translated from a foreign language, press reviews can also be considered a testimony of their reception, bearing a range of cultural and literary associations, which are revealed on the level of intertext in particular. At the same time, the review is neither autonomous nor autotelic, for it is conditioned by the very fact of the publication of the work to which it is devoted. It can be said that the review is a solely functional type of text as its aim is to recommend a particular literary work to the reader. For these reasons, a description of a review should also consider such aspects as the publishing market and marketing. In this sense, the text of a review comes as an expression of not only the intention of its author, but also the circumstances which are external to her or him.

If a given literary work has been reviewed on numerous occasions due to the fact that it attracts particular interest, the least effective method of description would be an exegetic characteristics of particular reviews. The author of this article proposes another practice, namely, encapsulating the scope of content appearing in the Finnish reviews of Anielka in the form a paradigm. One possible advantage of this strategy is that it can capture clear and distinct common spaces and thus result in a synthetic picture of the whole - a pattern which is comparable with other patterns. However, obtaining this picture of the whole based on media studies and literary history is not an end in itself - there is also a potential for references to intercultural communication and the paradigm of European culture. The reviews authored by Finnish journalists and literary critics are a testimony to the penetration into the otherness of Polish culture and an attempt to understand it also through the loci communes which continually appear in European literary tradition. Various types of reading associations and references to literary motifs, such as the mal du siècle or limproductivité slave, require analysis and interpretation in the context of intercultural communication and the paradigm of European culture. The Finnish reviews of Without Dogma can be treated as a contribution in this respect.

\section{Review content}

In this case, individual reviews have the status of a column type of text devoted to publishing news; they have a fixed location in the dailies and weeklies, which makes them easy to find for an average press reader. Column texts usually carry the title "Kirjallisuutta" [Literature], with such variants as "Uutta kirjallisuutta" [New Literature], "Kirjallisuus ja taide" [Literature and Art] or "Muutamia syyskirjoja" [Some 
Autumn Books]. They appear in the columns devoted to the topic of culture, which come after those with political information and comments. A review contained in such a column is thus a heteronomous and utilitarian text in the sense that it constitutes an element of the book market. It is thought to be important as an opinion aiming to promote the sale of a book and thus rarely discourages recipients from making their purchases. With slight exaggeration one may say that reviews of new books are uncritical and superficial, while, on the other hand, critical literary reviews must contain at least some elements of criticism. In other words, reviewers have little time to think things over, as they write almost "in real time", while critics take their time and wait for the voices of reviewers to fade before they speak their mind. Some of the former might not lose credibility despite having praised a poor product, while the latter may have their reputation shattered only because they have not been critical enough.

One may easily spot the advertising policy of most publishing houses in individual journals. On the one hand, there are reviews of the latest books and on the other paid for, and large, advertisement listings of them. The same bookselling information appears both in the reviews of Without Dogma and in the advertised Otava Publishing House listings, entitled "Kustannusosakeyhtiö Otava" [Otava Publishing House] or "Otovan uusimpia kirjoja" [The Latest Books from Otava Publishing House]. In the reviews we first focus on the bookselling information preceding the text, which includes the name and surname of the author (Henryk Sienkiewicz) and the translator (Maila Talvio), the number of pages of the two-volume work (553) and the price (paperback: 5.50 marks, hardback: 7 marks).

\section{Author - translator - literary genre}

Three elements may be considered an extension of bookselling information: the names of the author and the translator, since they guaranteed (advertised) the quality of the work and its translation, and a general genre qualification, aiming to inform the reader of the type of literature offered to them.

The surname Sienkiewicz was a brand of its own already: he is referred to as "the greatest Polish novelist", known to the Finnish reader from the translations of such works as Quo vadis, On the Field of Glory and Charcoal Sketches. The list of his translations had now come to include Anielka, a work "unique in several aspects" (Rev. 4). ${ }^{3}$ One of the reviews opens as follows:

The works of the well-known writer Henryk Sienkiewicz have by now gained their fame. The following titles have already been published in the Finnish language: Quo vadis, On

\footnotetext{
${ }^{3}$ References to particular reviews are made using their numbers as they appear on the list at the end of this article.
} 
the Field of Glory, Bartek the Conqueror, The Lighthouse Keeper, For Daily Bread. And now, along with other books for this autumn, his most valuable psychological novel, Anielka, finely translated by Maila Talvio into Finnish, has been released and met with great interest. (Rev. 5)

The reviewer for Turun Sanomat (Rev. 8) emphasises the fact that Sienkiewicz is the most popular Polish writer among the Finnish readers: he is the author of numerous stories and novels translated into Finnish, one of which, Quo vadis, was put on stage in Finland. The very title of this novel, seen as Sienkiewicz's tour de force and a brand, appears also in reviews for Tornion Laakso (Rev. 9) and Suur-Savo (Rev. 2), which stated that although Anielka was not written with such a great skill as Quo vadis, the reader would find it appealing.

In the most thorough review, including elements of critical analysis of the text, V. A. Koskenniemi calls Anielka "one of the more outstanding and intriguing works of modern fiction" (Rev. 3). At times, the reviews contain explanations of the novel's original title (in Polish it is Bez dogmatu - Without Dogma) and the origin of the title of its translation: Anielka (Rev. 10). There is no information, however, about the year of publication of the original (1890), which could be explained by marketing reasons rather than lack of knowledge. As Anielka was offered among the latest books, the reader might have considered it a recent work of Sienkiewicz. Still, this omission was not a deception. After all, Finnish readers got to know the works of this author from various periods of his writing career. Meanwhile, Bartek the Conqueror or For Daily Bread almost welcomed the reception as current works on account of their universal themes (service in a foreign army and emigration). Only one review contained information that the novel Without Dogma had been published in Polish more than twenty years earlier and translated into many languages, including German in 1892, under the title Ohne Dogma (Rev. 12).

The assessment of the translation is always positive. The author of one of the reviews expresses his joy that Anielka, a famous novel by Sienkiewicz, was selected to show this kind of literature in Finnish (Rev. 9). It is stressed that "the work of Maila Talvio is skilful and thorough" (Rev. 10) and that the result is not "solely a translation but, in certain places, a properly inspired interpretation" (Rev. 4). This aspect is underlined by the use of the term "Finnicisation" with regard to the original (which also occurs in the bookselling information) (Rev. 12). In one case a superlative term is used: "Finnicised masterpiece" (Rev. 10). Naturally the translator is free to use invention and cultural adaptation. Maila Talvio clearly took advantage of this right effectively, since her translation was perceived as skilful or greatly successful Finnicisation of Sienkiewicz's novel (who indeed expressed his consent for her translation of the work).

If we referred this to contemporary translation theories, we could say that in the reviewers' impression (we are talking about an impression here, and not about translation expertise) the "Finnicisation" of Sienkiewicz's work by Maila Talvio is 
a perfect example of "domestication", to use a term introduced by Lawrence Venuti, i.e. a translation which does not bear any signs of the "foreignness" of the original and brings it closer to the reader. The opposite of "domestication" is "foreignisation", namely, the highlighting of the linguistic and cultural differences of the original and thus bringing the reader closer to the country native to the writer through revealing its "exoticism" (Venuti, 2008). The term "foreign" with reference to the translated text is also a key category in the famous essay by Antoine Berman, "La traduction comme l'épreuve de létranger", published in 1985 (Berman, 2012). In line with this concept, translation itself is a deforming act, characterised by twelve tendencies, which he describes in detail. It is worth quoting one passage from this essay, which could explain why the "Finnicisation" of Sienkiewicz's novel is so easily acceptable and considered an asset by the Finnish reviewers:

Insofar as the novel is considered a lower form of literature than poetry, the deformations of translation are more accepted in prose, when they do not pass unperceived. For they operate on points that do not immediately reveal themselves. It is easy to detect how a poem by Hölderlin has been massacred. It isn't so easy to see what was done to a novel by Kafka or Faulkner, especially if the translation seems "good". The deforming system functions here in complete tranquillity. This is why it is urgent to elaborate an analytic for the translation of novels. (Berman, 2012, p. 243)

Several reviews emphasise that Anielka is a psychological novel in the form of a diary kept by the protagonist, Leon Płoszowski (Rev. 3, 4, 6, 10). The advantages of this form are of psychological and not narrative nature. As observed, the description of soul states related to love affairs and "subjective reflections of the ego" is never tiring since it "stems, above all, from the type of personality of the author and that unique, cultural manner in which he copes with his mirror images" (Rev. 6). One of the reviewers admits that "Anielka is one big, unrivalled diary, the best one I have ever read" (Rev. 2). According to some opinions, however, although the form of a diary enables a thorough analysis of the soul, it also has its disadvantages as it keeps "repeating the same things", that is, emotional states. This disrupts somewhat the reader's interest, despite the fact that "the description of emotional states was carried out perfectly" (Rev. 4). One of the reviewers points out that the novel may seem slightly lengthy for the reader who "expects an exciting plot and captivating twists", but its content is of psychological nature and, what is more, it provides an image of the life of the Polish gentry (Rev. 12). Critical notes are thus secondary as they concern, in fairness, the genre of psychological novel itself, and the awareness of the fact is pointed out by the authors who make them. Another reviewer writes that the work of Sienkiewicz is considered "the most unique psychological story in Polish literature" (Rev. 1). According to the most enthusiastic opinion, Anielka "is undoubtedly one of the best masterpieces that literature of recent decades has offered its readers" (Rev. 3). 


\section{The plot}

Although the reviews describe at times the plot of the novel, it is the creation of characters that the reviewers find much more important. This stems from the very essence of the genre of psychological novel, where the plot - in the Aristotelian sense of imitation of real life events - does not play such a role as in the classical novel, not to mention the picaresque novel or crime fiction. In other words, in the psychological novel the story of the world of events is at risk of narrative caricature, when almost everything takes place in the minds and emotions of the characters and not so much occurs outside of them. It is easy to trivialise the content of the work. The reviewers are aware of this and they must respond to the need to inform the reader of the content of the literary product on which they give their opinion. Consequently, they bring the audience closer, as in case of Anielka, to the elements of the world of events in the work, realising that they are just an introduction to the most significant issue - the feelings and emotions of the characters. Considering their focus, then, the issue of the plot becomes of less significance than the creation of literary characters. The Turun Sanomat's reviewer remarks that although the very plot of Anielka is a love story, the novel in fact deals with a precise and deep analysis of the most beautiful shades of the "portrait of love" between the protagonists (Rev. 8). The reviewer for Suur-Savo, in turn, emphasises that "from beginning to end it is a psychological novel" whose "assets do not lie in a thrilling story, it does not offer any unexpected twists of the plot or surprises, but in the fact that the more vibrant the spiritual life of the characters, the more splendid and intriguing its analysis" (Rev. 2).

Several reviews summarised the plot of Anielka, with the most detailed ones being those published in the women's magazine Naisten Ä̈ni and in Wiipuri. The reviewer for Naisten Ä̈̈ni (Rev. 12) first describes the birth of love between Leon and Anielka and how it grew, with an emphatic insight into the "inconceivable", growing "young feeling" of the female character, her emotions glittering with magnificent colours. The text comes as proof of a reading experience, which tends to be honest by nature. The reviewer's voice, then, conveys honesty and thus is bound to meet with appreciation on the part of the readers, who are used to the convention of expressing a subjective opinion of the value of literary works. The reviewer does not forget about the events of the plot and outlines the main stages of how they unfold (Leon's departure to Rome on receiving the message about his father's illness, Anielka's desperation and her marriage to another man, Leon's despair and wandering, his return and his efforts to regain the love of Anielka, her morally unwavering attitude, her pregnancy by her husband, her husband's suicide and her death). These stages are signalled by means of temporal phrases which introduce narration in the text of the review itself: "Time passes", "This time is gloomy for Leon..., "However, like a bolt from the blue..., "Then, an unexpected message comes..., "The next day the death comes" (Rev. 12). 
A detailed summary of the plot does not mean listing all its components. Quite the opposite, we may speak here of selective focus on the events related to the story of love between Leon and Anielka. Nevertheless, in this subjective review the world of events in the story is drawn up clearly, perhaps in too much detail: the reader gets to know the storyline and the tragic fate of Anielka before reading the book. It seems that too much is revealed and too little left unsaid.

The same may be noted about the review published in Wiipuri (Rev. 10), which outlines the plot of Anielka with equal precision and thus there is no need here to repeat the order of events referred to in the previous text. The review is equally emphatic and focused on the story of love of the two characters. However, the episodes of relationships with Laura Davis and Klara Hilst are described here more clearly. Another difference is that the reviewer tends to identify himself more with the point of view of Anielka, quoting her confessions several times.

In the review published in Aamulehti, the storyline of the novel is outlined in several sentences. The main character, a descendant of a Polish aristocratic family, does not believe in "everyday life values" - led astray by impulsive anger and "erotic emotion", he abandons Anielka, "a paragon of virtue" (Rev. 4). She then marries a man "devoid of spirituality", a businessman and nobleman called Kromicki. Leon makes use of all his abilities, knowledge and financial means to regain Anielka, but she remains adamant and rejects his efforts owing to her strong belief in the dogma of marriage being unbreakable. This is all the reviewer reveals, leaving the rest to the reader and adding that "all that the author has to say stems from this unfortunate state of affairs" (Rev. 4). This seems to be a critical note and it is not the only one. As a matter of fact, it amounts to putting the storyline in a nutshell. The reviewer notes that the plot is not "too extended or complex", but still the novel is gripping and holds the reader's attention. He also adds that "one ought to consider how such a simple plot may trigger such richness of thoughts" and concludes that this comes as proof of the writer's genius (Rev. 4).

The review which appeared in Vaasa (Rev. 5) features a similar summary of the plot. Anielka and Leon's love is so deep that it could certainly make both of them happy for the rest of their lives. Still, the circumstances beyond their control (the illness and death of his father, travel to Rome, fascination with "an Italian lady full of fire and passion") and his inborn scepticism make him forget about Anielka. Hurt in her feelings and pressed by her mother, she marries "a down-to-earth businessman". Leon returns to Poland and desperately strives to win back the heart of the lover he abandoned. But Anielka, although truly in love with him, remains faithful to her husband, treating marriage concluded in the church as holy. As described by the touched reviewer, she is "the most adorable personality one can encounter in literature". The writer, he adds, presents this unhappy love with "a perfect knowledge of psychology". 
Anielka dies as a victim of her great love, or more so, as a victim of Leon's love, as he decides to commit suicide.

In the reviews under consideration the plot is subject to the principle of fragmentary presentation and even the seemingly detailed description of events published in Naisten Ä̈̈ni or in Wiipuri is quite selective. This is in line with the nature of this press genre: a review cannot be limited to a mere summary of the plot. It is supposed to encourage the prospective reader to read the book and to arouse rather than satisfy his or her curiosity.

\section{The characters}

It is quite similar in the case of the characters, who are also subject to the principle of fragmentary presentation in the reviews. This is quite apparent, above all, in focusing on the main characters of the novel, Leon and Anielka, and pushing the secondary ones into the background or, most frequently, omitting them altogether. Even the characters who are close to the protagonists are disregarded and if they do appear in the reviews they are referred to using their family relations rather than names or surnames (Anielka's mother, husband, Leon's aunt). Naturally, the more extensive reviews, as in the case of Uusi Aura (Rev. 3), mention the names of the key secondary characters, such as Kromicki and Laura Davis. Nevertheless, the principle of fragmentary presentation is observed. One may say that as a result the supporting characters become part of the background or disappear entirely from the sight of the reviewer, just like Klara Hilst, the German pianist in love with Leon; her importance was mentioned in Aamulehti (Rev. 1) and Wiipuri (Rev. 10). And yet, this character is not indifferent to the protagonist, whom she truly loves. Importantly, she manages to reject his insincere love, thus resembling Anielka in the sublimity of her feelings.

The main characters of the novel are Leon, the author of the intimate diary, and Anielka P., the object of his fascination, whom he describes (we only know the initial of her surname). In the case of Leon, the reviewers appear in the role of psychologists, while in case of Anielka - in the role of moralists. In Uusi Aura (Rev. 3) we read that the main character is a person worthy of condemnation from the social point of view. On the other hand, from the "purely psychological" point of view he is a neurotic representative of "the old, sophisticated race, too complicated in its soul structure to take life as it is". He suffers from "the disease of over-analysing", which causes constant distrust towards the feelings of not only others but also his own. This is the essence of his tragedy.

The review in Uusi Suometar (Rev. 7) considers the issue of the male and the female dimensions of the personality of the protagonist. The former is expressed by his passion "of constant studying, analysing and assessing" life and the states of his 
soul, cold analysis performed consistently and persistently. This "rather male" ego is coupled with the "more female" ego, "an almost girlish sensitivity and delicateness", where even the gentlest touch on a nerve provokes a reaction that is disproportionate to the causes. Such a structure of mind makes him naturally prone to being an unhappy person. The obsession of self-control makes him helpless in his struggle to take control over his fate. Among the motives of actions there is no place for the factor of free will and he becomes enslaved by his female ego with all its "whims and sympathies as well as disgusts based on its own, incomprehensible nervous medicine". The reviewer also raises the issue of the intellectual capacity of the main character. Intelligence - in his opinion - has become a "permanent state of the soul" of Płoszowski, outside objective reality. As a result, his knowledge has been limited, he does not know or search for answers to any of the questions and he has no beliefs. He lives "without dogma" (reference was drawn to the Polish title), "philosophising into pieces" about his fate and destroying his love. Constant self-analysis has led to the emergence of his second, fatal "toxic ego".

The reviewer for Wiipuri (Rev. 10) referred not as much to the powers of psyche as to Płoszowski's personality. He defined him as "a complete sceptic", thoroughly doubting the rules and dogmas that shape human life. Such a person never strives for any goal, not wishing to commit to anything. There is nothing he can rely on but - as noticed by the reviewer - a certain type of moral foundation for him is aesthetics, as can be seen in a quotation from the protagonist: "I recoil from many things not because they are wicked but because they are ugly". ${ }^{4}$ This attitude does not protect him from the rules of life, which proves to be a lesson to be learnt by him from his promiscuous Paris episode.

\section{The Slavic type}

It needs to be stressed that intertextual references made in the reviews are strictly related to the creation of the character of Płoszowski and never to that of Anielka. Overall, these references do not concern contemporaneous psychological novels but involve associations with the great literary masterpieces of the eighteenth and nineteenth centuries, which may reveal the conservative tastes of the reviewers, who, at the same time, pay attention to the state of literary knowledge of the readers and their reading experiences. In particular, the intertext concerns the representative features of Płoszowski as a "Slavic type", inspired by the thoughts of this character, who calls himself "a genius without portfolio", displaying what is referred to as limproductivité

${ }^{4}$ This and all subsequent quotations from Without Dogma come from the English translation by Iza Young (Sienkiewicz, 1893/2004), available at https://www.gutenberg.org/files/11686/11686.txt 
slave, Slavic unproductivity. Although Polish reviewers also raise this theme, they do not emphasise it as much as the Finnish ones. While for the former the Slavic nature is shy (in political terms the Poles consider it as favouring Russia), this is not the perception of the Finns, for whom Slavic nature is simply strange, something that Poles, for various reasons, cannot or do not wish to see. In this case strangeness is cognitively positive, since it carries along the points of view that are missing in the reading of the novel by the writer's compatriots. For this reason, Finnish opinions are interesting, particularly those that raise the issue of the "Slavic nature" of Anielka's main character.

The reviewer for Helsingin Sanomat (Rev. 6) comments on Płoszowski as "an authentic Slavic" type, who had been present in literature before but whom Sienkiewicz gave a significant frame. In his opinion, the creation of this character, powerless and deprived of any beliefs, is similar to that of Oblomov in a novel by Ivan Goncharov. At the same time, however, there are rather significant differences between them: Count Płoszowski leads "an intense, edgy life" and is more intelligent and spiritual than "an unfortunate observer" created by the Russian writer. His curse is his Slavic helplessness; the reviewer quotes a sentence from the novel: "God has given us bow and arrow, but refused us the power to string the bow and send the arrow straight to its aim". The review in Uusi Aura (Rev. 3), in turn, quotes an extensive passage in which Płoszowski refers to limproductivité slave. The reviewer observes a similarity between the creation of this character and the creation of Oblomov. He makes associations not only with Goncharov's novel, but also with the works of Goethe and Kierkegaard, concluding that the protagonist of Anielka is representative of "the Slavic race":

It [Anielka] is, to be more precise, a story of man's sorrows, similar to those in Goethe's Werther or The Seducer's Diary by Kierkegaard, to mention two similar stories from the past century. ${ }^{5}$ The case of Sienkiewicz is neither as morbidly sophisticated as Kierkegaard's nor as simply natural as young Goethe's. It is somewhere in between those two but, above all, it is representative of the Slavic race, with Sienkiewicz's protagonist as an example. (Rev. 3)

Another reviewer writes that Płoszowski is "very representative of the Slavic type", a life dilettante whose "highly-developed scepticism" prevents him from "building anything lasting and makes him indecisive when faced with a decision" (Rev. 11). Limproductivité slave is suggestively imagined as a snake wrapped around the protagonist (Rev. 2). These and other opinions display the Finnish stereotype of a Slavic person as one immersed in complexities of their own spirituality and unable to "take life in its simplicity". The reviewer for Naisten Ääni writes about this straightforwardly, observing similarity between the creation of Płoszowski and Pushkin's Onegin: "He [Płoszowski] greatly resembles Eugene Onegin, whereby new

${ }^{5}$ To be more precise, from the second half of the eighteenth century and the first half of the nineteenth century, respectively; the time between their publication dates was about seventy years. 
characteristics of the Slavic type of passivity and emotionality are depicted: lack of action and effort undertaken at the right time and the attendant struggle and suffering that this entails" (Rev. 12).

For the Finnish reviewers, then, Goncharov and Pushkin are a significant point of reference when it comes to l'improductivité slave. Płoszowski's reflexivity is seen as important for the creation of this character, while his unproductivity is perceived in terms of his typicality or representativeness. One may say that they make him more Russian than the reviewers or Polish literary historians would wish to notice. This is reflected in a Freudian slip made by one of the reviewers, who consistently referred to Płoszowski using the name Ploszow (Rev. 4). The same can be said about calling Sienkiewicz an author who displays "the skill of presenting moral dilemmas which is characteristic of Slavic writers" (Rev. 11).

What is striking in the reviews of Anielka is the fact that there are no allusions to Turgenev's works (Rudin, translated into Finnish by Maila Talvio in 1896, and The Diary of a Superfluous Man (Dnevnik lishnego cheloveka)). The analogy between the characters of Płoszowski and Rudin could have provided an opportunity for the interpretation of coinciding motifs of limproductivité slave and a superfluous man.

\section{Mal du siècle}

The typicality of Płoszowski is underlined by yet another cultural motif, broader than limproductivité slave, namely, his representativeness as a personification of Chateaubriand's mal du siècle, sickness of the century. The reviewer for Uusi Suometar (Rev. 7) defines this condition as "a manifestation of cultural development which has gone one-sided", finding its victims from amongst social elites. This "disease of the mind", which belongs to the domain of morality and psychology rather than medicine, is symbolised by Hamlet. However, in modern times it has ceased to be a condition associated with princes and higher classes, becoming widespread in society and regarded as "a sign of the era" and part of the psychological structure of "the modern human being", who suffers from "unique spiritual anaemia" resulting from excessive intellectualisation of modern culture and education. The reviewer further notes that Anielka is a biased book in the sense that the author, on the example of Płoszowski, wishes to reveal the tragedy which may be caused by over-intellectualisation of culture. Sienkiewicz conducts an experiment - he describes the course of chemical reaction that combines two substances: the social one, today called habitus of an aristocrat, ${ }^{6}$ with personal oversensitivity, in other words: excess of luxury and

${ }^{6}$ The notion of habitus is used here in accordance with Pierre Bourdieu's concept as presented in La Distinction: Critique sociale du jugement (Bourdieu, 1979) and Le sens pratique (Bourdieu, 1980). In these studies, the eminent French sociologist defines "habitus" as, among others, a specific system of social 
idle overabundance with the hypertrophy of psychological states. The experiment has proven that intellect led to an extreme in such laboratory conditions reveals "its own toxicity". Nevertheless - as added by the reviewer - another issue is whether the results of this experiment may be considered universal. It seems rather doubtful, taking into consideration that the writer's laboratory operates in artificial conditions of the reality he creates.

In the text published in Uusi Aura (Rev. 3) - which, as mentioned above, is an outstanding historical-literary sketch - the reviewer also writes about the mal $d u$ siècle, the earlier exemplifications (prototypes) of which may be found in Manon Lescaut by Prévost, Die Leiden des jungen Werthers by Goethe or La confession d'un enfant du siècle by Musset. However, Sienkiewicz, despite all the indicated literary references, has managed to develop his original perception of the phenomena he describes. His novel, according to the reviewer, is not solely about a description of the mal du siècle, which has become proverbial, but rather about "a tragedy of the whole nation and race" - it is not about an individual, but about the state of ethnic drama he represents: the defeated Poland. The following idea expressed by the Finnish reviewer over a hundred years ago may sound as paradoxical for the Polish literary historian as it is thought-provoking: "Anielka is not only an unreachable object of Płoszowski's love, but also life itself, flesh-and-blood, active, happy life, which does not succumb to anyone who fails to approach it openly and straightforwardly, anyone who loses his energy for fruitless analysis and self-agony instead" (Rev. 3).

Yet another thought, expressed in the review published in Aamulehti, corresponds to this idea. According to it, Sienkiewicz's novel has a national meaning since it reveals "the spiritual secrets of Polish aristocracy" (Rev. 4). It shows significant possibilities which fail to materialise owing to a lack of life purpose on their part. Aristocracy is a class doomed to failure, as can be seen in what Płoszowski says to Anielka: "I might have been your happiness, and became your misfortune". By no means is it just a personal reflection as the reviewer relates it to the historical fate of Poland, drawing on another thought of the very same character:

It is a confession from the depths of his soul and it may be referred to the role played by the whole Polish gentry in shaping the country's fate. This work is, in other words, a reflection in which the noble-born counts and countesses of the unfortunate Poland may see that they, according to the author, are the fragile Sèvres china right next to common clay, ordinary citizens of the country. (Rev. 4)

dispositions - "a mental structure [...] inculcated into all minds socialized in a particular way", a kind of a "socialized body" (Bourdieu, 1998, pp. 66, 81). In his conversation with Roger Chartier, Bourdieu uses the term "habitus" while referring to aristocracy. He defines the "aristocratic habitus" as the "habitus of distance from the mediocre, the commonplace, the trivial, the petty bourgeois" (Bourdieu \& Chartier, 2010, p. 58). 
In the two reviews quoted above the motif of mal du siècle is subject to a noteworthy transformation, and specifically - ethnicisation: Płoszowski represents aristocratic Poland, defeated, lacking a will to live (which, as opposed to him, is embodied by Anielka). Naturally, the Finnish point of view is partly built on a stereotype of Poland, defeated owing to the faults of the aristocracy. However, it lies deeper in the folk tradition of Finnish culture, in the democratic ethos of the Finns and their spirit of social cooperation, which is often, sometimes enthusiastically, addressed by the Polish press. The Finnish perspective is epitomised in the words of Turun Sanomat's reviewer. He claims that the way of thinking typical of the decadent movement of the end of the nineteenth century, represented by Płoszowski, is natural for the nations in which the long-lasting cultural processes shaped the dignified and educated aristocracy. "This type is foreign to us", he writes, and concludes in a surprising way: "yet, there is no less charm in it, or may be even more" (Rev. 8).

\section{Anielka}

In the reviews, the character of Anielka is assessed in moral terms. She stands in opposition to Płoszowski, who attracts a far greater overall interest being a more complicated and hence more interesting creation. Although the title of the Finnish translation points at Anielka as the main character - which is an interesting decision and certainly a unique marketing move (the title Anielka sounds far more interesting than an enigmatic, depersonalised Without Dogma) - the truth is that it is Płoszowski, the author of the intimate diary, who is the protagonist. He idealises Anielka as the object of his love, but - frankly speaking - the reviewers idealise her even more, using his words about her, such as "ideal", "perfection", for the purpose. Indeed, the thought that he is in love with an ideal only appears in the interpretations. Anielka from the reviews is "a very rare ideal of a woman even in literature", she is really "pure and noble", which enables her to turn her lover's passion into spiritual love (Rev. 5). She is "an innocent, pure creature who believes in life", "young and beautiful, raised in utmost respect to the principles of faith and life" (Rev. 10). She loves Leon despite having married - out of despair after being rejected - a man who is "the opposite of her beautiful and fragile nature" (Rev. 10). She feels unhappy but she is unable to change this state of affairs. She confesses this tragedy of feelings to Leon, saying that she would be ready to sacrifice anything for love but her honesty is "that last plank of salvation" - her words appear in an extensive quotation in the review (Rev. 10). Anielka is similarly assessed in another review: although she is "pure nature", the foundation of her morality is fidelity; she is consumed by the psychomachia between the wedding vow and the first love and this is the source of her despair, even though she comes out victorious from this struggle (Rev. 12). She is 
"too good-hearted Catholic" to allow herself for even the "slightest allusion as to her favour" towards Leon (Rev. 11).

The reviewers seem to admire Anielka, one might say, as a laboratory experiment of perseverance, total faith in dogma. They are thus unable to doubt the naturalness of behaviours of the character, who does not distance herself from Leon, the source of her suffering, but somewhat masochistically keeps him close, without the slightest suspicion on the part of her closest ones. Her passion cannot be fulfilled (as this would be infidelity) or left to slowly fade away (had she distanced herself from the object of her love) or sublimated (through motherhood). In fact, she turns out to be entirely powerless, not much unlike Leon, incapacitated by his passiveness. They are both slowly heading towards self-destruction, not being able to see any way out of this maze. Sienkiewicz presents the results of the processes occurring in utterly different moral structures and analyses the attendant psychological dispositions: complete disbelief in dogmas on the one hand and an absolute belief in them on the other. Fixation, and thus readiness to bear the final consequences, is what these two extremes have in common. The reviews lack a critical distance with regard to the main female character of the novel, although, obviously, this is a point of view of interpreters from a different era.

\section{Final assessment}

Final assessment is the key structural element of the press review. The reader needs to know the final verdict of the reviewer and whether a given book is worth reading. Sometimes, under a strong impression, an enthusiastic assessment comes right at the beginning of the text, as is the case in Wiipuri: "Anielka is a must to be read, a masterpiece of the Polish master - Sienkiewicz! Once you read it you will be reliving the events that shaped the fate of pure, charming Anielka in your thoughts for a long time" (Rev. 10). Normally however, the final assessment tends to be placed at the end of the text, as in the case of a review quoted above. Its author underlines that Anielka is "an outstanding masterpiece" which is "devoid of any artificiality whatsoever and any unnecessary ornaments". Some passages of this confession of modern life, soaking in scepticism and irrationalism, read like the most amazing poem. It is not a "book for everyone", since the novel is addressed to more advanced and sophisticated readers (Rev. 10). Anielka is compared to a work of poetry by yet another reviewer, who recommends the novel as "a poem about pure first feeling of a young woman which is not fulfilled" (Rev. 12). The opinion claiming that the author of this "exquisite work" "displays his true grit" on almost every page belongs to metaphoric register (Rev. 2).

The final assessment is superlative in all cases. In Aamulehti, the main value of Anielka is the writer's skill of "psychological exploration of love life" and his 
handling of "the deepest analysis of the heart", with the following conclusion: "Thus, this novel about aristocracy becomes aristocratic also in terms of its reception and so it will not be in the scope of interest of a superficial reader" (Rev. 4). The reviewer for Vaasa recommends it to "anyone who wants to read truly valuable literature" (Rev. 5). The reviewer for Helsingin Sanomat, in turn, believes that the novel could have been written in a more concise manner since the readers may not avoid the temptation of sweeping through the pages. However, this "intelligent and sophisticated narration in a melancholic tone" does not scare off the readers. Individual tragedy becomes a symbol of tragedy of the humankind and this is where the deeper value of the book lies (Rev. 6). In the review published in Uusi Aura the novel is assessed as "a good lesson for many young novelists", and, although not very eventful, it is considered to be "absorbing and exciting". This stems from the fact that "Sienkiewicz plays a far more incredible instrument than a legion of novelists" (Rev. 3). The reviewer for Uusi Suometar balances certain doubts regarding thought processes underlying the novel with an opinion that Sienkiewicz approached the topic "with great passion", creating Anielka as "one of the most far-reaching and sharpest vivisections on the sensitive soul of our times performed in literature" (Rev. 7).

\section{Differences between Finnish and Polish reviews of Without Dogma}

For the sake of comparison, it is worth noting some general differences between the Finnish and Polish reviews of the novel. The most important one is the fact that the Finnish reviewers were more interested in the character of Anielka; Polish reviewers, on the other hand, focused on Płoszowski. The translator's decision to change the abstract title Without Dogma to Anielka, a specific name, was in line with the convention of using the name or surname of the protagonist as the title, as in the case of Anna Karenina, Oblomov or Rudin. In the article penned on the occasion of Sienkiewicz's 70th birthday, Maila Talvio strongly emphasised the equal status of Anielka, who was created as if in contrast to the "overdelicate male" epitomised in the character of Leon Płoszowski; she represents "the daughters of the nation in which women sustained the sense of national self-confidence for the entire century" (Naisten Ääni no. 17, 13 May 1916, p. 211). Hence, providing a different title than the original was a well-thought-out decision of the translator, which was also of importance for the book market as it meant that Sienkiewicz's work is a book about a woman - and not only about Płoszowski - and so, also a book for women.

This factor is missing in the Polish reviews, even the ones published in the most important women's magazines: Tygodnik Mód i Powieści (no. 11, 14 March 1891, pp. 86-87) and Bluszcz (no. 29, 16 June 1891, pp. 228-230). The first review focuses on Płoszowski being pulled apart as a man "plunged into a pool of uncontrolled 
bestiality", whereas Anielka is considered merely an embodiment of gentleness serving the function of a "protest" against such a life. The second review also deals with the fact that Płoszowski fills the readers with disgust, and Anielka's words directed at him reveal "the whole emptiness and littleness of this man". In general, the Polish reviews focus on pedantic analyses of Płoszowski's personality and his mental condition.

Naturally, the reviews feature Polish intertextual references, e.g. in the form of allusions to Adam Mickiewicz or Zygmunt Krasiński as well as such contemporary writers as Aleksander Mańkowski. What is missing, however, as it has already been mentioned, is Russian intertext (so important for the Finnish reviewers). Nevertheless, its lack is compensated for with several discussions of the reviews of the novel in the Russian press, which were reprinted in Polish journals, e.g. "Rosjanin o powieści Bez dogmatu" [A Russian on Without Dogma] in Kurier Polski (no. 241-242, 5-6 September 1891). What made the best impression was an excellent sketch "Old Types of Russian Fiction Writers in Recent Polish Literature" by Leonid Egorovich Obolenskii (Russkoe Bogatstvo no. 5-6, 1891), summarised in detail in the Prawda weekly magazine (no. 36-38, 3-17 September 1892). Obolenskin interpreted the protagonists of Without Dogma in the context of Pushkin's and Turgenev's characters.

As discussed above, the Finnish reviewers considered the complex of socio-historical issues in the novel in an interesting manner, for instance the importance of the motif of limproductivité slave, associated with the causes of Poland's fall. Although the Polish reviewers analysed this motif as well, they did not emphasise it as much.

The field of comparison can be significantly expanded, but it goes beyond the scope of this article. What deserves a mention, however, is the issue of knowledge about Finnish literature and culture among Polish readers as well as the psychological discussion in Finland and Poland. The interest in Finnish culture and literature in Poland intensified, especially after 1905 . Finland was written about with enthusiasm for many reasons (Stępnik, 2014); one of the examples is the special "Finnish" issue of Tygodnik Ilustrowany (no. 40, 5 October 1907), featuring illustrations by Finnish painters. Several articles were devoted to Finnish literature. One of them stressed the role of Jooseppi Julius Mikkola, a professor at Helsinki University, as "the main linguistic axis of Finland and Poland" and his wife Maila Talvio as a translator of the works of Polish writers into Finnish (p. 813).

In the nineteenth century, Finnish literature was fundamentally realistic, while after 1890 there emerged a "reaction against realism", called "national neo-romanticism" and stemming from European roots (Laitinen \& Apo, 1991, p. 89). However, psychological novels and books on psychology continued to receive interest in Finland. Like in Poland, European classics were translated, published and commented on in literary criticism: Stendhal, Hamsun, Strindberg, Bourget, Dostoevskiu (although Turgenev was much more popular). If we asked a question about the comparison of the Finns' interest in the psychological novel (and the human psyche in general) with 
the corresponding interests of Poles, the answer would be difficult. In this case, it is problematic to formulate an unequivocal opinion.

One could indicate a detail that cannot be generalised, but provides food for thought. For example, Freud was probably more popular in Finland than in Poland, just like another Viennese - Otto Weininger, the author of the famous Geschlecht und Character, published in 1903, presenting shocking proposals about the superiority of male intellect and spirituality over those of women. In 1904, 1905 and the following years the book was discussed by Finnish critics. A work by the Norwegian writer Hulda Garborg Kvinden Skabt af Manden [Woman Created by Man], describing the Geschlecht und Character, gained extraordinary popularity. The Finnish reviewers of Without Dogma presumably knew Weininger's book, but they did not refer to it (although it could serve as a suitable key to describing Płoszowski's character). It would seem that Weininger's study could be of greater interest to Polish modernists. Meanwhile, it was condemned in 1904 by the feminist magazine Nowe Stowo. In 1905, it was given more attention by the monthly Świat Płciowy (a lecture by Felicja Nossig, shocked but also intrigued by Weininger's concept), and the weekly Prawda - following Scandinavian literature - discussed the aforementioned book by Hulda Garborg. Then the interest disappeared. It should be noted, however, that Polish modernism was particularly sensitive to gender issues, which is clearly manifested in Stanisław Przybyszewski's writings.

This name provokes a comment on the change of interpretative contexts resulting from the over twenty-year difference between the date of the original Polish edition and the Finnish translation of Sienkiewicz's novel. In 1890, Polish critics perceived Bez dogmatu as a work heralding modernism, exposing the problem of the psyche of the individual. Hence the success of Przybyszewski's plays and the success of psychological prose, developed by the leading writers of Young Poland, headed by Stefan Żeromski; in the early 1890s, psychological novels by Aleksander Mańkowski and Ignacy Dąbrowski met with considerable interest. On the other hand, in 1913 Finnish reviewers did not regard Without Dogma as a modernist novel because since the publication of Przybyszewski's Zur Psychologie des Individuums (1892) it was rather him who served to Finns as an example of a Polish writer representing modernism, or, in other words, the trend of artistic modernity (the terms modernism and modernismen became popular in Finnish art criticism only in the 1920s and 1930s, in a different sense than before the First World War). The works of this writer were constantly present on the Finnish book market, also in Swedish and German, and their publication was accompanied by voices from literary critics and theatre reviewers. In addition, some of his plays were staged at the prestigious Finnish National Theatre (Suomen Kansallisteatteri), including Złote runo (The Golden Fleece), translated by Maila Talvio in 1904, just three years after the Polish premiere. The reception of this drama, describing the destructive power of the sex drive, was strikingly different than 
in the case of Without Dogma: Przybyszewski's play was modernist (it was suspected of being immoral in Poland), and Sienkiewicz's novel was used by Finnish reviewers to praise the model of fidelity represented by Anielka.

\section{Conclusions}

Translation is an act of cultural communication, an invitation to become familiar with culture other than one's own. This invitation is accompanied by press reviews, which constitute an element of book market and advertising. They are utilitarian texts, written mostly by journalists and typically published in the usual column of a magazine. Their aim is to assess the quality of literary works and the quality of their translations, and thus to provide a certain guide that informs readers about the current offer. They promote books which appear on price listings of publishing houses and they very rarely discourage anyone. Unlike reviewers, literary critics are more inclined to write about certain faults. These two roles must be distinguished regardless of how often it happens that literary critics or historians assume the role of reviewers. Press reviews are not, however, solely utilitarian texts with overt or covert commercial functions. They also give opinions concerning the literary value of a work. Since they are written straight away (they cannot be postponed for too long), they are subjective and characterised by axiological content. This is also the case of the twelve reviews of Anielka in the Finnish press, published between late 1913 and January 1914, shortly after the release of the translation on the market.

This concentration in time enables describing the reviews under consideration as a paradigm consisting of comparable elements and providing a full image of the object of study. This methodological approach brings, as it seems, some positive results. It reveals the Finnish perception of Sienkiewicz's novel more than twenty years after the release of the Polish original. Cultural distance does not at all turn out to be the factor of misunderstanding. Quite the opposite, the described paradigm documents, as it seems, something uniquely important, namely, that "strangeness" provides an opportunity for perception of the work that is different than in the culture from which it originates. It carries along new, somewhat external aspects of the object's view, conditioning the extension of its cognition. It enhances the status of the translation through its axiological equalisation with the original. The structure of the original, as Jacques Derrida writes, is marked with a prospective requirement of becoming a translation, so, paradoxically, the original is indebted to the translator: "The original is the first debtor, the first petitioner, it begins by lacking and by pleading for translation" (Derrida, 1985, p. 184). 


\section{Reviews of Anielka (Without Dogma) in the Finnish press in the order of publication}

1. Aamulehti no. 238, 15 October 1913, p. 5 (no signature), republished in over twenty daily papers in October and November 1913.

2. Suur-Savo no. 119, 18 October 1913, p. 3; author's initials: W. P.

3. Uusi Aura no. 248, 26 October 1913, p. 6; author's initials: V. A. K. [Veikko Antero Koskenniemi].

4. Aamulehti no. 256, 5 November 1913, p. 5; author's initials: -ii-.

5. Vaasa no. 132, 8 November 1913, p. 3; author's initials: -i-n.

6. Helsingin Sanomat no. 262, 9 November 1913, p. 8; author's initials: A. M. Tn.

7. Uusi Suometar no. 267, 15 November 1913, pp. 5-6; author's initials: -o K-a.

8. Turun Sanomat no. 2677, 21 November 1913, p. 3; author's initials: -rtt-.

9. Tornion Laakso no. 92, 25 November 1913, pp. 2-3; author's initials: V. K. T.

10. Wiipuri no. 274, 26 November 1913, pp. 2-3; author's initials: W. I. W.

11. Aika no. 11-12, 1 January 1914, pp. 606-607; author's initials: V. A. K. [Veikko Antero Koskenniemi].

12. Naisten Ä̈̈ni no. 2, 31 January 1914, pp. 26-27; author’s initials: I. S.

Access: Kansalliskirjasto - Digitaaliset aineistot (The National Library of Finland - Digital Collections), https://digi.kansalliskirjasto.fi/

\section{Bibliography}

Berman, A. (2012). Translation and the trials of the foreign (L. Venuti, Trans.). In L. Venuti (Ed.), The translation studies reader (3rd ed., pp. 240-253). Routledge.

Bernardini, L. (2018). Przed czy po Quo vadis? Włoska recepcja Bez dogmatu (1899-1916). In O. Płaszczewska (Ed.), “Bo każda książka to czyn...” Sienkiewicz (pp. 81-97). Wydawnictwo Uniwersytetu Jagiellońskiego.

Bourdieu, P. (1979). La Distinction: Critique sociale du jugement. Minuit.

Bourdieu, P. (1980). Le sens pratique. Seuil.

Bourdieu, P. (1998). Practical reason: On the theory of action (R. Johnson, Trans.). Stanford University Press.

Bourdieu, P., \& Chartier, R. (2010). The sociologist and the historian. Polity Press.

Derrida, J. (1985). Des Tours de Babel (J. F. Graham, Trans.). In J. F. Graham (Ed.), Difference in translation (pp. 165-207). Cornell University Press.

Derrida, J. (2001). What is a "relevant" translation (L. Venuti, Trans.). Critical Inquiry, 27(2), 174-200. https://doi.org/10.1086/449005 
Laitinen, K., \& Apo, S. (1991). Historia literatury fińskiej: Zarys (C. Lewandowska, Trans.). Zakład Narodowy im. Ossolińskich - Wydawnictwo.

Sienkiewicz, H. (2004). Without dogma (I. Young, Trans.). Project Gutenberg. https://www.gutenberg.org/files/11686/11686.txt (Original work published 1893).

Stępnik, K. (2014). Recepta na Rosję. Obraz zachowań Finów w prasie warszawskiej przed I wojną światową. In A. Jarzyna \& Z. Kopeć (Eds.), Obraz Rosji w literaturze polskiej XX wieku (pp. 13-43). Wydawnictwo Nauka i Innowacje.

Świerczyńska, D. (2015). Bibliografia literatury polskiej "Nowy Korbut": Henryk Sienkiewicz. Instytut Badań Literackich PAN.

Szal, K. (2013). Finnish literature in Poland, Polish literature in Finland: Comparative reception study from a hermeneutic perspective. University of Eastern Finland. https://erepo.uef.fi/ bitstream/handle/123456789/11946/urn_isbn_978-952-61-1044-8.pdf

Venuti, L. (2008). The translator's invisibility: A history of translation (2nd ed.). Routledge.

\title{
The Paradigm of Finnish Reviews of Without Dogma by Henryk Sienkiewicz: Observations on the Issue of Intercultural Communication and the Functioning of Common Motifs of European Culture
}

\begin{abstract}
The translation of Henryk Sienkiewicz's novel Without Dogma into Finnish, entitled Anielka (1913), generated considerable interest in the Finnish press, evidenced by as many as twelve reviews of the work. The article analyses these reviews, describes them in terms of a paradigm and presents their functioning on the book market. Taking into account cultural distance between Poles and Finns, the reviews are approached as a testimony to intercultural communication, which was enabled thanks to community - the paradigm of European culture and its common motifs, such as the mal du siècle or limproductivité slave, the latter highlighted by Sienkiewicz and particularly interesting for Finnish reviewers. Cultural distance turns out to be a factor that reveals new aspects of interpretation of Without Dogma and, more broadly, the specificity of Finnish thinking about Poland.
\end{abstract}

Keywords: Henryk Sienkiewicz; Without Dogma (Anielka); reviews; Finnish press 1913-1914; intercultural communication 


\section{Paradygmat fińskich recenzji Bez dogmatu Henryka Sienkiewicza. Obserwacje dotyczące kwestii komunikacji międzykulturowej i funkcjonowania wspólnych motywów kultury europejskiej}

\section{Streszczenie}

Przekład powieści Henryka Sienkiewicza Bez dogmatu na język fiński pod tytułem Anielka (1913) spotkał się z widocznym zainteresowaniem prasy fińskiej, czego poświadczeniem jest aż 12 recenzji tego dzieła. Przedmiotem zainteresowania autora artykułu są te właśnie recenzje, które poddał analizie i opisał w ramach paradygmatu oraz przedstawił ich funkcjonowanie na rynku księgarskim. Biorąc pod uwagę odległość kulturową Polaków i Finów, autor opracowania potraktował te recenzje jako świadectwo komunikowania międzykulturowego, umożliwionego przez wspólnotę, jaką stanowi paradygmat kultury europejskiej i jego obiegowe motywy, jak motyw choroby wieku czy wyeksponowany przez Sienkiewicza motyw l'improductivité slave, szczególnie interesujący dla recenzentów fińskich. Odległość kulturowa okazała się czynnikiem odsłaniającym nowe aspekty interpretacji Bez dogmatu i - szerzej - specyfikę fińskiego myślenia o Polsce.

Słowa kluczowe: Henryk Sienkiewicz; Bez dogmatu (Anielka); recenzje; prasa fińska 1913-1914; komunikacja międzykulturowa

Prof. Dr hab. Krzysztof Stępnik, Professor at the Faculty of Political Science and Journalism, Maria Curie-Skłodowska University in Lublin; PhD - 1979, Faculty of Humanities, Maria Curie-Skłodowska University; habilitation in Literary Studies 1990, Faculty of Humanities, Maria Curie-Skłodowska University; professor - 1998. Author of eleven books and over a hundred scholarly papers, essays and reviews; editor and co-editor of 32 collective volumes. He is especially interested in the history of the Polish and world press and descriptions of historical, political and cultural events in the media from the late nineteenth and early twentieth centuries. The method described in his book Henryk Sienkiewicz: Studia $z$ mikrobiografiki prasowej [Henryk Sienkiewicz: Studies in Press Microbiography] is based on the information from historical Polish journals. This method allowed for the reconstruction of Sienkiewicz's biography. In his latest book Sienkiewicz globalny [Sienkiewicz as a Global Writer], he describes the public biography of the author of Quo vadis on the basis of newspapers from all over the world. 
Bibliography (selected): Filozofia metafory [Philosophy of metaphor], Lublin 1988; O Sienkiewiczu: Mowy - kazania - wiersze [About Sienkiewicz: Speeches - sermons - poems], Pamiętnik Literacki 87(4), Wrocław (Wroclaw) 1996, 15-48; Macedonia $w$ prasie polskiej (1903-1914) [Macedonia in the Polish press (1903-1914)], Lublin 2014; Henryk Sienkiewicz: Studia z mikrobiografiki prasowej [Henryk Sienkiewicz: Studies in press microbiography], Lublin 2016; Sienkiewicz globalny [Sienkiewicz as a global writer], Lublin 2017.

Correspondence: Krzysztof Stępnik, Institute of Social Communication and Media Science, Maria Curie-Skłodowska University, Lublin, e-mail: krzysztof.stepnik@ poczta.umcs.lublin.pl

Support of the work: The study was conducted at the author's own expense.

Competing interests: The author declares that he has no competing interests.

Publication History: Received: 2020-11-18; Accepted: 2021-05-19; Published: 202112-21. 